\title{
THE EFFECT OF NON-EQUILIBRIUM ANNEALING ON THE SWELLING BEHAVIOR OF POLYSTYRENE AND STYRENE-ACRYLONITRILE COPOLYMER
}

\author{
By Hirohisa Yoshida and Yasuji Kobayashi \\ (Department of Industrial Chemistry, Faculty of Technology, \\ Tokyo Metropolitan University, Fukazawa, Setagaya-ku, Tokyo)
}

\begin{abstract}
The relaxation behavior of polystyrene (PS) and styrene-acrylonitrile copolymer (SAN) with annealing at temperatures below $T_{\mathrm{g}}$ (non-equilibrium annealing) was studied as a function of the excess enthalpy which was calculated from the absorption of thermal energy as measured by DSC. And also, the non-equilibrium annealing effect on the swelling behavior of PS and SAN with ethanol was investigated. The rate of enthalpy relaxation of SAN with annealing below $T_{\mathrm{g}}$ was equal to that of PS at the same $T_{\mathrm{g}}-T_{\mathrm{a}}$. It was turned out that the rate of relaxation was hardly affected by the presence of 38 mole\% of acrylonitrile. It was expected that the mechanisms of enthalpy relaxation process of PS and SAN were identical. The swelling test with ethanol was carried out for the original and annealed samples at $40^{\circ} \mathrm{C}$. It became clear that the swelling process of polymeric glasses were affected with annealing below $T_{\mathfrak{g}}$. The non-equilibrium annealing delayed the beginning of swelling. However, the diffusion rate of ethanol was affected slightly with annealing after the beginning of swelling. The swelling process of PS was affected with annealing more than SAN.
\end{abstract}

\section{INTRODUCTION}

Recently, there has been increased interest in the structural and property changes that occur in glassy polymers with annealing below glass transition temperature $\left(T_{\mathrm{g}}\right){ }^{\left.1{ }^{1}\right)}$ It is assumed that structures and properties change with time towards some presumed equilibrium state as the result of coupled local fluctuations in the volume and the molecular conformations. This "non-equilibrium annealing behavior" has been known ${ }^{2,3)}$ to reduce the specific volume and the enthalpy of polymer. The annealing process has been analyzed as the function of annealing temperature $\left(T_{\mathrm{a}}\right)$ and time (t) by using specific volume ${ }^{2)}$ or excess enthalpy ${ }^{3}$ ) which was calculated from the absorption of thermal energy as measured by differential scanning calorimetry (DSC).,

We have studied the effect of chemical structure $^{5)}$, tacticity ${ }^{6}$, molecular weight ${ }^{7)}$ and hydrogen bonding ${ }^{8)}$ on the non-equilibrium annealing process. Previous investigations have shown that the enthalpy relaxation accompanying the annealing of a glassy polymer at temperatures below $T_{\mathrm{g}}$ is caused by a cooperative motion of a few consecutive repeat units. Further, the molecular mobility of glass decreased with annealing, and this phenomenon was supported by the studies of stress relaxation. ${ }^{\text {") }}$

It is expected that the transportation and diffusion processes are affected with annealing. However, only a few work about the annealing effect on the diffusion process have been reported. Chen ${ }^{10)}$ investigated the sorption of simple alkane permeants in polycarbonate having different annealing history. Fechter et $\mathrm{al}^{11)}$, have reported that the sorption and diffusion of $\mathrm{CO}_{2}$ in poly(methyl methacrylate) was affected with annealing. A practical aspect of the dependence of solvent absorption kinetics upon thermal history of the network epoxy system has been discussed by Kong et al. ${ }^{12)}$

In this study, the non-equilibrium annealing process of polystyrene (PS) and styrene-acrylonitrile copolymer (SAN) were analyzed by using excess enthalpy. In addition, the annealing effect on the diffusion and swelling processes were discussed. 


\section{EXPERIMENTAL}

Sample

Atactic PS used through experiment was STYRON 666 (Asahi Daw Co.). A commercially available SAN was used for experiment. Acrylonitrile content of this copolymer was 38 mole\% which was determined by elemental analysis. PS and SAN were purified by the fractional precipitation from tetrahydrofran (THF) solution with water as a precipitant. The precipitated polymers were dried to constant weight in vacuo above $T_{\mathbf{g}}$. Ethanol as a diffusant was purified by the ordinary method.

\section{Sample preparation}

PS and SAN were pressed in a hot press with a condition of $40 \mathrm{~kg} / \mathrm{cm}^{2}$ at $160^{\circ} \mathrm{C}$, and cooled slowly. The thickness of obtained films were 0.5-2 mm. Sample specimens for the swelling test $(10 \mathrm{~mm} \times 30 \mathrm{~mm} \times 2 \mathrm{~mm})$ were cut from the pressed film by using a heat cutter at $160^{\circ} \mathrm{C}$ in order to make all surfaces of samples into a same condition.

\section{Thermal analysis and annealing}

Differential scanning calorimeter, Model DSC II manufactured by Perkin Elmer Co. was used to obtain the heat capacity difference between liquid and glassy states and the apparent energy absorption in the glass transition region. The heating rate used was $10^{\circ} \mathrm{C} / \mathrm{min}$. Sample weight used were $10-20 \mathrm{mg}$.

In order to eliminate the effect of previous thermal history, each samples were heated to temperature $30^{\circ} \mathrm{C}$ above the corresponding $T_{\mathrm{g}}$ 's before measurement. After that, each samples were cooled toward the annealing temperatures at $10^{\circ} \mathrm{C} /$ min. Each samples were annealed in the DSC sample cell. The thermal measurement and annealing were carried out under a nitrogen atomosphere.

The specimens of the samples for the swelling test were sealed in glass tubes filled with nitrogen gas and quenched to the annealing temperatures from $116^{\circ} \mathrm{C}$ for PS and $129^{\circ} \mathrm{C}$ for SAN.

\section{Swelling test}

The swelling test was carried out as follows. Samples were held in ethanol which were controlled at $40^{\circ} \mathrm{C}$. At sampling times, samples were taken up from ethanol and weighed after wiping off ethanol from sample surface with a filter paper.

\section{RESULTS AND DISCUSSION}

\section{Enthalpy relaxation process}

The heat capacity $(C p)$ changes of PS and SAN during heating at $10^{\circ} \mathrm{C} / \mathrm{min}$ were shown in Fig. 1. Both $C p$ in the glassy state $\left(C p_{\mathrm{g}}\right)$ and $C p$ in the liquid state $\left(C p_{1}\right)$ are linearly dependent on temperature within experimental error. $T_{\mathrm{g}}$ was estimated from the intersection between the initial base line and the sloping portion of the line as the base line shifts during the transition as shown in Fig. 1. The difference of $C p$ between the liquid and the glassy states at $T_{\mathrm{g}}\left(\Delta C P=C p_{1}-C p_{\mathrm{g}}\right)$ was estimated by linear extrapolation of $C p_{1}$ and $C p_{\mathrm{g}}$ to $T_{\mathrm{g}} . T_{\mathrm{g}}$ and $\triangle C p$ were $86^{\circ} \mathrm{C}$ and $0.364 \mathrm{~J} / \mathrm{g}$ for PS, $99^{\circ} \mathrm{C}$ and $0.427 \mathrm{~J} / \mathrm{g}$ for $\mathrm{SAN}$.

PS were cooled from $116^{\circ} \mathrm{C}$ to $72^{\circ} \mathrm{C}$ at $10^{\circ} \mathrm{C} /$

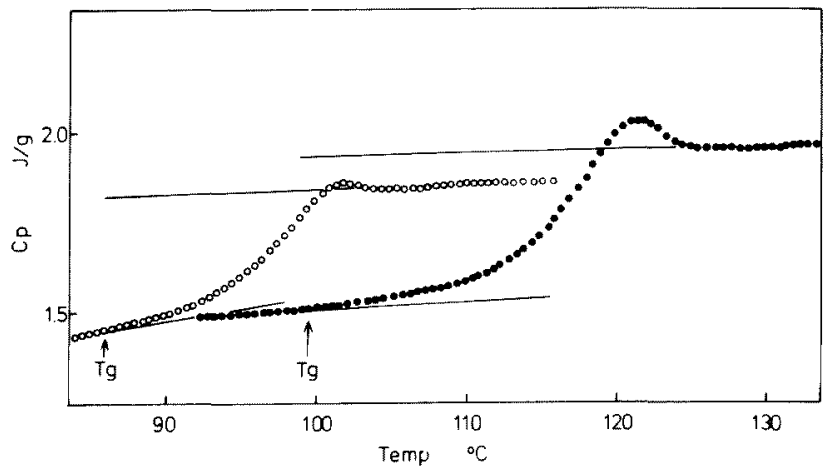

Fig. 1 Heat capacity changes with temperature for PS (O) and SAN (O) obtained by heating at rate of $10^{\circ} \mathrm{C} / \mathrm{min}$. 
$\min$, and $C p$ changes were measured after annealing. Several sets of $C p$ versus temperature data obtained during heating were shown in Fig. 2. For the annealed samples, not only $C p$ jump at $T_{\mathrm{g}}$ but also the peak of $C p$ were observed. As $\Delta H=\Delta C p d T$, the decrease of enthalpy with annealing can be obtained as the difference between the integral value of DSC curves for the original and the annealed samples, assuming that the enthalpies of liquid state are equal with each other. The estimating method of excess enthalpy $(\Delta H t)$ have been reported previously. ${ }^{13)}$ The excess enthalpy was defined as follows.

$$
\begin{aligned}
\Delta H t= & \Delta C p\left(T_{\mathrm{g}}-T_{\mathrm{a}}\right) \\
& -\left[\int_{T_{\mathrm{a}}}^{T_{\mathrm{g}}+30}\left(C p_{\mathrm{a}}\right) d T-\int_{T_{\mathrm{a}}}^{T_{\mathrm{g}}+30}\left(C p_{\mathrm{o}}\right) d T\right]
\end{aligned}
$$

where, $C p_{o}$ and $C p_{a}$ are $C p$ of the original and the annealed samples, respectively.

The obtained $\Delta H t$ are plotted against the annealing period in Fig. 3. The annealing temperatures are shown in figure. The values of $T_{\mathrm{g}}-T_{\mathrm{a}}$ are shown in parentheses. For both samples, the time-temperature superposition seems to be possible only by shifting the enthalpy relaxation curves along time axis.

Following the previous studies on the volume ${ }^{14)}$ and the enthalpy relaxation ${ }^{15)}$, the relaxation process could be approximated as follows.

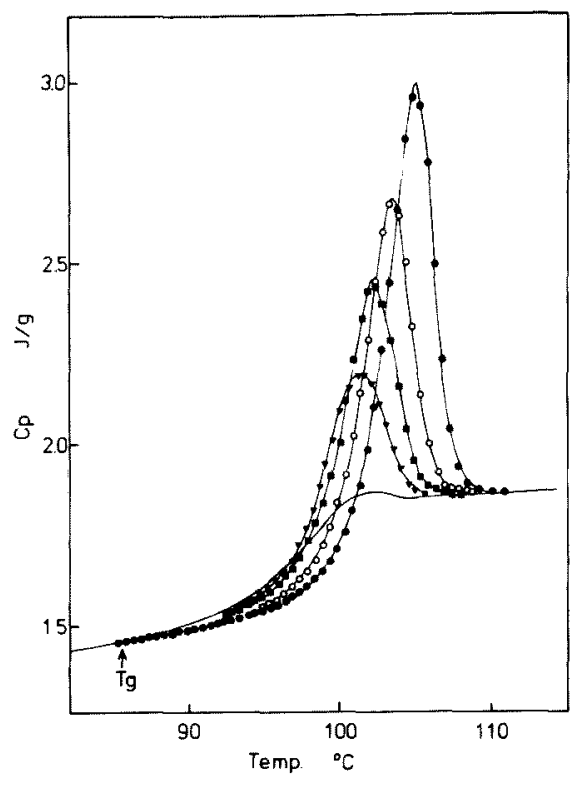

Fig. 2 Heat capacity changes with temperature for annealed PS obtained by heating at rate of $10^{\circ} \mathrm{C} / \mathrm{min}$. Samples were annealed at $72^{\circ} \mathrm{C}$ for $1 \mathrm{hr}(\boldsymbol{\nabla}), 6 \mathrm{hrs}(\boldsymbol{\square}), 20 \mathrm{hrs}(0)$ and $100 \mathrm{hrs}$ () after cooling from $116^{\circ} \mathrm{C}$ at rate of $10^{\circ} \mathrm{C} / \mathrm{min}$. Solid line shows heat capacity change of original PS.

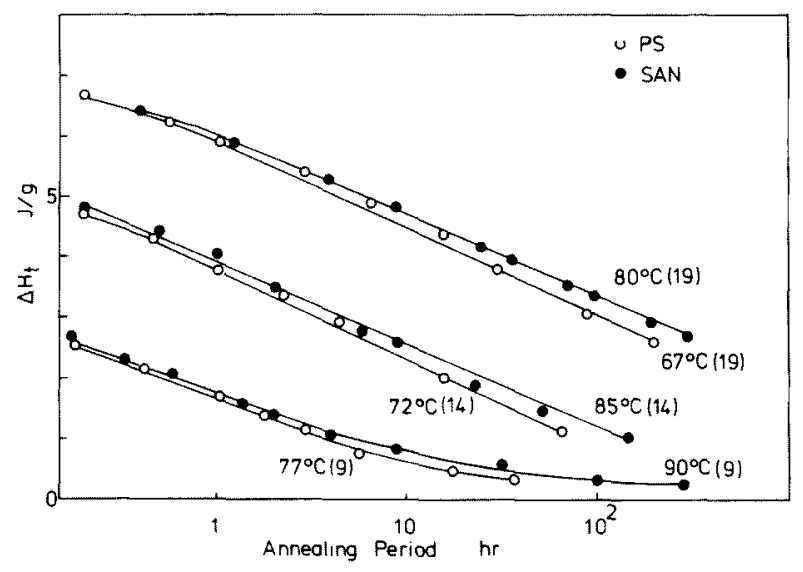

Fig. 3 Excess enthalpy $(\Delta H t)$ changes with annealing time for PS (O) and SAN (O). Annealing temperatures are shown in figure, and values of $T_{\mathrm{g}}-T_{\mathrm{a}}$ are shown in parentheses. 




Fig. 4 Variation of $\ln \left(\Delta H t / \Delta H_{\mathrm{o}}\right)$ with annealing time for PS (O) and SAN (O). Annealing temperatures are shown in figure, and values of $T_{\mathrm{g}}-T_{\mathrm{a}}$ are shown in parentheses.

$$
\Delta H t=\Delta H_{\mathrm{o}} \exp \left[-t / \tau_{(t)}\right]
$$

where, $\tau_{(t)}$ is the relaxation time which changes with the annealing period. $\Delta H_{\mathrm{o}}$ is the excess enthalpy of the original sample. The value of $\ln \left(\Delta H t / \Delta H_{o}\right)$ were plotted against the annealing period in Fig. 4. The annealing temperatures were shown in figure, and the value of $T_{\mathrm{g}}-T_{\mathrm{a}}$ were shown in parentheses. At same $T_{\mathrm{g}}-T_{\mathrm{a}}$, both samples show the same relaxation curve. Considering from these data, the mechanism of enthalpy relaxation for PS and SAN are thought to be identical. For polyacrylonitrile, $T_{\mathrm{g}}$ and the enthalpy relaxation process were hardly observed by using a DSC as a results of crystallinity. In a previous paper $^{8)}$, we reported that the hydrogen bonding restricted the enthalpy relaxation process of styrene/4-hydroxystyrene copolymer. However, the enthalpy relaxation process of SAN was not restricted in spite of the presence of 38 mole \% of acrylonitrile.

\section{Swelling process}

The diffusion equation along the thickness direction of the plane can be described by Fick's law.

$$
\partial C / \partial \theta=D\left(\partial^{2} C / \partial X^{2}\right)
$$

where, $D$ is the diffusion coefficient, $C$ is the concentration of penetrant in polymer, $\theta$ is the diffusion time, and $X$ is the distance from the surface. The concentration of penetrant in polymer is initially zero, and the concentration of penetrant at polymer surface is constant during the swelling measurement. If $M_{\theta}$ denotes the total amount of penetrant which enters polymer during time $\theta$, and $M_{\infty}$ is the corresponding amount during infinite time, the solution of equation (3) is given by ${ }^{16)}$

$$
\frac{M_{\theta}}{M_{\infty}}=l-\frac{8}{\pi^{2}} \sum_{n=0}^{\infty} \frac{1}{(2 n+1)^{2}} \exp \left\{\frac{-D_{0}(2 n+1)^{2} \pi \theta}{l^{2}}\right\}
$$

where, $l$ is the thickness of film. Equation (4) can be rewritten at large $\theta$, as follows;

$$
\log \left\{1-\frac{M_{\theta}}{M_{\infty}}\right\}=\log \frac{8}{\pi^{2}}-\frac{\pi^{2} D_{0}}{2.303 l^{2}} \theta
$$

At small $\theta$, equation (4) can be simplified as follows;

$$
\frac{M_{\theta}}{M_{\infty}}=4\left(\frac{D_{0} \theta}{\pi l^{2}}\right)^{1 / 2}
$$

The normalized swelling curves of the original and the annealed SAN which have different thickness $(l=0.5,1,2)$ were shown in Fig. 5 . The swelling time $\theta=0$ shows the beginning of the swelling test. For the original sample, the normalized curve obtained by combining data from three 




Fig. 5 Normalized swelling curves for original (O) and annealed SAN at $80^{\circ} \mathrm{C}$ for 65 hrs (O).

samples having the different thickness shows the typical Fickian diffusion. However, the swelling curve is sigmoid in shape and the time lag is observed for SAN annealed at $80^{\circ} \mathrm{C}$ for $65 \mathrm{hrs}$. For the initial stage, the diffusion behavior of the annealed sample cannot be described adequately by Fick's law. However, the swelling curve of the annealed sample shows a linear dependency of $\theta^{1 / 2}$ at large $\theta$.

In order to compare with equation (6), the values of $\log \left\{l-\left(M_{\theta} / M_{\infty}\right)\right\}$ were plotted against the swelling time $\theta$ in Fig. 6 . The original sample shows a linear relationship within the experimental error. For the annealed sample, a linear relationship was observed at large $\theta$. Therefore, the swelling process of the original sample can be analyzed as the Fickian diffusion, and the diffusion coefficient is obtained by using equation (6). Also, the swelling process of the annealed sample at large $\theta$ may be described by Fick's law, and the diffusion coefficient may be obtained by using equation (5).

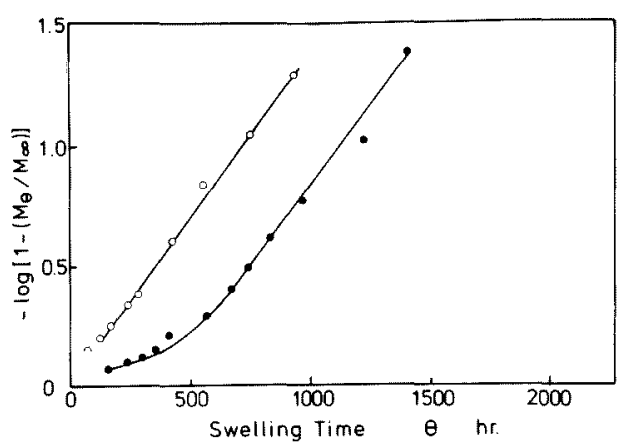

Fig. 6 Replotted swelling curves against swelling time $(\theta)$ for original (O) and annealed $\mathrm{SAN}$ at $80^{\circ} \mathrm{C}$ for $65 \mathrm{hrs}(-$ ).

In order to estimate the effect of annealing on the diffusion process, the swelling test was carried out for PS and SAN which have different annealing conditions. The normalized swelling curves were shown in Fig. 7 for PS annealed at $77^{\circ} \mathrm{C}\left(T_{\mathrm{g}}-T_{\mathrm{a}}\right.$ $\left.=9^{\circ} \mathrm{C}\right)$, in Fig. 8 for SAN annealed at $90^{\circ} \mathrm{C}$ $\left(T_{\mathrm{g}}-T_{\mathrm{a}}=9^{\circ} \mathrm{C}\right)$, in Fig. 9 for PS annealed at $67^{\circ} \mathrm{C}$ $\left(T_{\mathrm{g}}-T_{\mathrm{a}}=19^{\circ} \mathrm{C}\right)$ and in Fig. 10 for SAN annealed at $80^{\circ} \mathrm{C}\left(T_{\mathrm{g}}-T_{\mathrm{a}}=19^{\circ} \mathrm{C}\right)$.

The effect of annealing appears on the swelling curves as the time lag, that is, the annealing delays the beginning of swelling. This phenomenon can be explained qualitatively as a result of decreased free volume with annealing, though the free volume is a parameter for characterizing physical behavior and not a directly determinable quantity such as the specific volume. However, enthalpy $(H)$ is defined by

$$
H=U+P V
$$

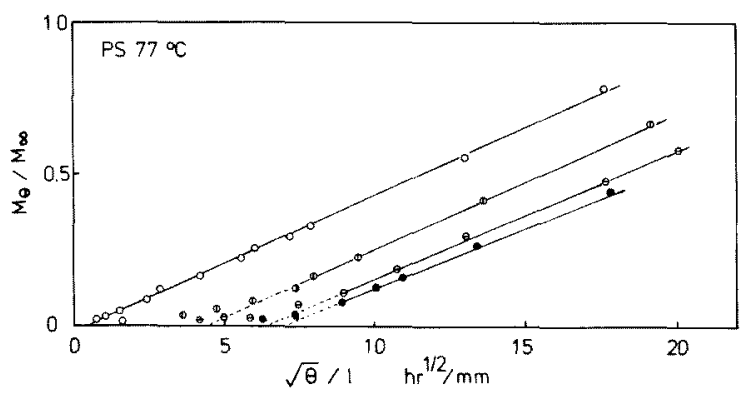

Fig. 7 Normalized swelling curves for original PS $(O)$ and annealed PS at $77^{\circ} \mathrm{C}$ for $23 \mathrm{hrs}(D), 71 \mathrm{hrs}(\ominus)$ and $113 \mathrm{hrs}(\mathbf{O})$. 
where, $U, P$, and $V$ are internal energy, pressure, and volume, respectively. Therefore, the decrease in enthalpy at a constant pressure can be rewritten as follows;

$$
\Delta H=\Delta U+P \Delta V
$$

It will be noted that the enthalpy decrease with annealing can be described as a function of the decrease of the free volume fraction. Actually, the density increased with annealing, e.g. $1.073 \mathrm{~g} / \mathrm{cm}^{3}$ for the original SAN and $1.074 \mathrm{~g} / \mathrm{cm}^{3}$ for $S A N$ annealed at $80^{\circ} \mathrm{C}$ for $65 \mathrm{hrs.}{ }^{17)}$

The time lag obtained from Figs. $7-10$ was plotted against the enthalpy decrease $\left(\Delta H_{\mathrm{d}}\right)$ obtained by DSC measurement in Fig. 11. The value of $T_{\mathrm{g}}-T_{\mathrm{a}}$ are shown in parentheses. For both samples, the relationship between the time lag and the enthalpy decrease was observed even

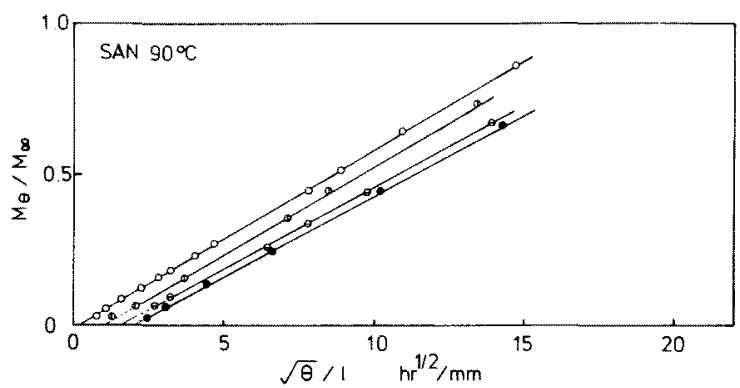

Fig. 8 Normalized swelling curves for original SAN (O) and annealed SAN at $90^{\circ} \mathrm{C}$ for $1 \mathrm{hr}(\oplus), 8 \mathrm{hrs}(\Theta)$ and $24 \mathrm{hrs}(\mathbf{O})$.



Fig. 9 Normalized swelling curves for original PS (O) and annealed PS at $67^{\circ} \mathrm{C}$ for $29 \mathrm{hrs}(\mathcal{D}), 61 \mathrm{hrs}(\theta)$ and 87 hrs (O).

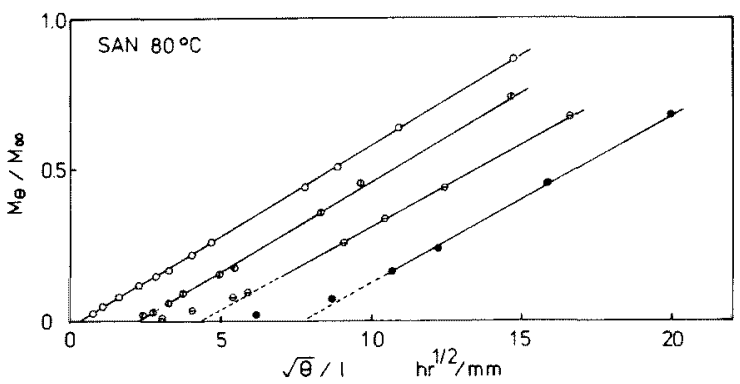

Fig. 10 Normalized swelling curves for original SAN (O) and annealed SAN at $80^{\circ} \mathrm{C}$ for 19 hrs (D), 42.5 hrs $(\Theta)$ and 65 hrs (O). 
if samples were annealed at the different temperatures. At the same value of the enthalpy decrease, the time lag of PS is longer than that of SAN. This fact shows that the swelling process of PS is affected with annealing more than SAN. The sufficient discussion concerning the annealing effect on the swelling process can be hardly given in terms of the free volume. However, we presume the annealing effect as follows. The free volume of glass decreases with the non-equilibrium annealing. This phenomenon is caused by a result of the limited segmental motion. For SAN, the free volume which is dispersed near the flexible segment (styrene) decreases faster than that in the neighborhood of the hard segment (acrylonitrile). Therefore, the free volume may distribute heterogeneously in the neighborhood of acrilonitrile after long time annealing. On the other hand, the free volume may distribute homogeneously in the annealed PS. If the beginning time of swelling (time lag) depends on the free volume distribution, the solvent will attack at first the neighborhood of acrylonitrile selectively.

The diffusion coefficients $\left(D_{0}\right)$ obtained from Figs. $7-10$ by using equations (5) and (6) were plotted as a function of the enthalpy decrease $\left(\Delta H_{\mathrm{d}}\right)$ in Fig. 12. Equation (6) applied in the range of $M_{\theta} / M_{\infty}$ about 0.2 to 0.6 for the annealed samples. The values of the diffusion coefficient obtained by using equation (5) and (6) show a good agreement for the original sample. The value of $T_{\mathrm{g}}-T_{\mathrm{a}}$ are shown in parentheses. For both

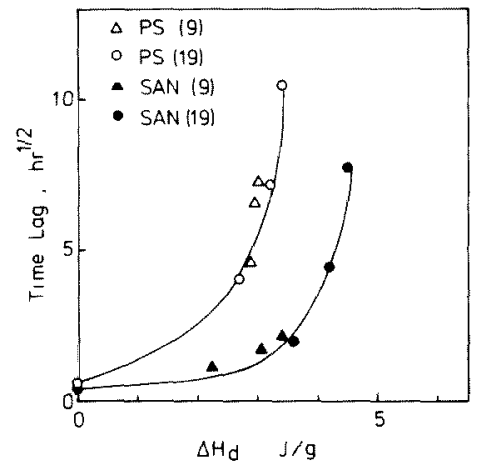

Fig. 11 Relation between time lag and enthalpy decrease with annealing $\left(\Delta H_{\mathrm{d}}\right)$ for PS and SAN. Values of $T_{\mathrm{g}}-T_{\mathrm{a}}$ are shown in parentheses.

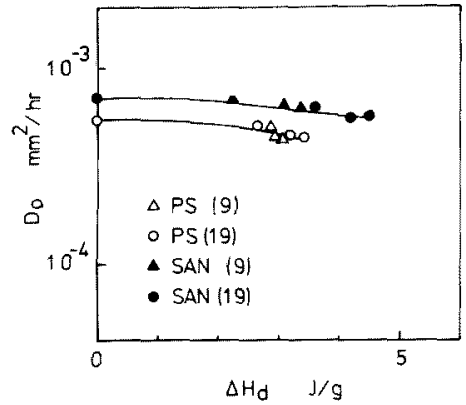

Fig. 12 Relation between diffusion coefficient of ethanol $\left(D_{0}\right)$ and enthalpy decrease with annealing $\left(A H_{\mathrm{d}}\right)$. Values of $T_{\mathrm{g}}-T_{\mathrm{a}}$ are shown in parentheses.

samples, $D_{\mathrm{o}}$ decreases slightly with annealing. The similar tendency was observed in the case of the migration of acrylonitrile monomer from SANaqueous solution system. ${ }^{17)}$ Since the free volume of glass increases and $T_{\mathrm{g}}$ decreases with swelling, the annealing effect on the diffusion coefficient may decrease.

\section{CONCLUSION}

The non-equilibrium annealing process of PS and SAN was investigated as a function of excess enthalpy. The rate of enthalpy relaxation of SAN with annealing at temperatures below $T_{\mathrm{g}}$ was equal to that of PS at same $T_{\mathrm{g}}-T_{\mathrm{a}}$. It was turned out that the rate of relaxation was hardly affected by the presence of 38 mole\% of acrylonitrile. From these fact, the mechanism of enthalpy relaxation process of PS and SAN seems to be identical.

It became clear that the swelling process of polymeric glasses were affected with annealing at temperatures below $T_{\mathrm{g}}$ from the swelling measurement of ethanol into PS and SAN. Especially, the beginning time of swelling was affected extremely with annealing. The non-equilibrium annealing delays the swelling process of glasses. However, the diffusion rate of ethanol was affected slightly after the beginning of swelling. The swelling process of PS was affected with annealing more easily than SAN. 


\section{REFERENCES}

1) A. J. Kovacs, J. M. Hutchinson and J. J. Aklonis; "The Structure of Non-Crystalline Materials", Taylor and Francis, London (1977)

2) A. J. Kovacs; Fortschr. Hochpolym. Forsch., 3, 394 (1963)

3) S.E. B. Petrie; J. Polym. Sci.. A-2, 10, 1255 (1972)

4) R. R. Lagasse; J. Polym. Sci. Polym. Phys. Ed., 20, 279 (1982)

5) H. Yoshida and Y. Kobayashi; J. Macromol. Sci., B21, 565 (1982)

6) H. Yoshida and Y. Kobayashi; Polymer J., 14, 925 (1982)

7) H. Yoshida and Y. Kobayashi; Rep. Prog. Polym. Phys. Japan, 25, 255 (1982)

8) H. Yoshida, K. Nakamura and Y. Kobayashi; Polymer J., 14, 855 (1982)
9) L. L.E. Struik; "Physical Aging in Amorphous Polymers and Other Materials", Elsevier, New York (1978)

10) S. P. Chen; Polym. Eng. Sci., 21, 922 (1981)

11) J. M. H. Fechter, H. B. Hopfenberg and W. J. Koros; Polym. Eng. Sci., 21, 925 (1981)

12) S. E. W. Kong, G. L. Wilkes, J. E. McGrath, A. K. Banthia, Y. Mohajer and M. R. tant; Polym. Eng. Sci, 21, 943 (1981)

13) H. Yoshida and Y. Kobayashi; Sen-i Gakkaishi, 37, T-458 (1981)

14) M. Uchidoi, K. Adachi and Y. Ishida; Polymer $J ., 10,161$ (1978)

15) H. Suga and S. Seki; J. Non-Crystal. Solids, 16, 171 (1974)

16) J. Crank; "The Mathmatics of Diffusion", Claredon Press, Oxford (1975)

17) H. Yoshida, R. Yoshida and Y. Kobayashi; Sen-i Gakkaishi, 38, T-457 (1982)

ポリスチレンならびにスチレンノアクリロニトリル

共重合体の膨潤挙動におよぼす非平衡熱処理効果

\footnotetext{
東京都立大学工学部工業化学科 吉田博久, 小林靖二

ガラス軽移温度 $\left(T_{\mathrm{g}}\right)$ 以下の温度域での熱処理による ポリスチレン(PS)ならびにスチレン/アクリロニトリ 儿其重合体 (SAN) の緩和挙動をDSCの吸熱ピークか ら得られる過剩エンタルピー量を用いて解析した。さら にこの非平衡熱処理が，エタノールによるPSとSANO 膨潤挙動におよぼす効果についても検討を行った。 $T_{\mathbf{g}}$ 以下の温度での熱処理によるSANのエンタルピー緩和 速度は， $T_{\mathrm{g}}-T_{\mathrm{a}}$ 加同じ温度に扔いてはPS の緩和速度 と等しかった。さらに38モル男のアクリロニトリル成分

とから，PSとSANのエンタルピー緩和機構は同じであ ると予想した。エタノールによるPSよSANの未姏理な らびに熱処理試料の $40^{\circ} \mathrm{C}$ におりる臌潤試験を行った。 高分子ガラスの膨闌過程が， $T_{\mathrm{g}}$ 以下の温度での熱処理 によって影響を受りることが諗められた。非平衡熱処理 によって膨潤の開始は遅れるが, 膨潤が開始した後のエ タノールの高分子ガラス中への拡散速度はあまり熱処理 によって影響を受けない。PSの膨潤過程の方がSANの 場合より季熱処理を受り易い。
} による、緩和速度への影響は誌められなかった。このと 